\title{
Developing English For Specific Purposes (ESP) Module For Computer Science Students' Vocabulary Mastery
}

\author{
${ }^{1}$ Fitri Palupi Kusumawati, ${ }^{2}$ Syaifudin Latif Darmawan, ${ }^{3}$ Siti Latifah \\ Universitas Muhammadiyah Metro \\ 1 fitripalupi85@yahoo.com
}

\begin{abstract}
This development research aimed to develop a learning module for students of Compter Science, to determine the feasibility of the module, and to determine the students' response towards the module. This study used Research and Developmet (R\&D) type of ADDIE model (Analysis, Design, Development, Implementation, and Evaluation). The module was developed based on the results of the research. The results of the feasibility of the module showed the following points: 1) The material expert and the lecturer of the Computer Science Department gave percentage of $69,63 \%$ under the range of $66.67 \%<p \sim \leq 80 \%$ which means that the developed module gets "B" score and in the "GOOD" category, 2) The media expert and the lecturer of Computer Science Department gave percentage of $75,3 \%$ under the range of $66.67 \%<p \sim \leq 80 \%$ which means that the developed module gets "B" score and in the "GOOD" category 3) The students of Computer Science Department, through the questionnaire, also gave positive response with the total score of 2034 and percentage of $69,63 \%$ which lies in the range of $60<\mathrm{P} \leq 80 \%$, and in the " $\mathrm{B}$ " and "positive"category. To get the information about the students' response towards the module, it was done through interview. The results of the interview showed that the students showed good response towards the module. In sum, it can be concluded that the module for Computer Science Department students is eligible and can be used as media to teach English.
\end{abstract}

Keywords : research and development, english for specific purposes (ESP), learning module, computer science.

How to Cite: Kusumawati, F. P., Darmawan, S. L., Latifah, S. (2018). Developing English For Specific Purposes (ESP) Module For Computer Science Students Vocabulary Mastery

English Language Teaching Educational Journal, 1(1), 13-21.

\section{INTRODUCTION}

Learning vocabulary is fundamental to support the learners to master English, because the ability of students to read and comprehend the subject material is relatively determined by their vocabulary. When the students have good vocabulary, they can understand paragraphs and texts better. Basically most learners know how important the words in a language is and they also realize that vocabulary learning strategies can be a very helpful device in their vocabulary learning journey. On the other side, for teachers, teaching vocabulary is very important not only for the students in school level but also in university level, one of them is Muhammadiyah University of Metro. 
Computer Science is one of the majors available in Muhammadiyah University of Metro which aims at preparing the students to face the global world. The students of this department are expected to know things related to the computer science field especially know how to solve computer problems, how to design computer network and to understand computer components. Therefore, on graduating from the department, the students can directly work. One of the ways to prepare the students to be as expected is by giving them English. When the students are qualified, they will be able to apply for a job successfully.

In teaching English to Computer Science department, a lecturer should have appropriate media to make the learning more interesting and thus the students do not feel bored. In addition, the process of learning should be varied too so that the students feel enjoyable and fun during the process. And this is a challenge for the lecturer! One of the ways to make interesting and enjoyable class is by using media as media can be used to motivate the students in the learning process. To use media effectively a lecturer needs creativity because creative media will increase the probability of the students to learn more and better. In sum, a lecturer should create various teaching media to increase interests of the students.

However, during the learning, the researcher found some problems in the students of Computer Science Department, especially when learning English for Specific Purposes (ESP). The problems were: students lack the vocabulary, the students' vocabulary mastery is still low, most of the students have relatively low learning motivation, and the students were difficult to translate the Computer Science terms into English. Furthermore, the students were difficult to learn English (ESP) because the book used only contains the exercises and less material explanation.

Based on the problems identification above, the researcher choose to develop an instructional media that can make students have practice and improve their vocabulary independently. By doing such a study, it's hoped that it can help students to learn English more easily and successfully.

\section{Theoretical Reviews on Terms Related to the Study}

According to Handayani (2007) vocabulary is knowledge of word and meaning. Based on the statement, vocabulary is all the words in a language that are familiar and used by someone to comunicate with each other. According to Lewis (in Tanto, 2014) there are four categories of vocabulary i.e. Listening, Speaking, Reading, Writing vocabulary. So, in English there are four skills that should be mastered, and each skill needs vocabulary mastery.

According to Hornby (2009) development is the process of producing or creating something new or more advanced. During the process of development, the important things need to pay attention on are innovation and creativity. According to Sugiono (2009) Research and development is a research method which can be used to produce a certain product, and test the effectiveness of the 
product. Based on the explanation, it can be concluded that research and development is a research method aims to produce certain products and test the validity and effectiveness of the product in its apllication.

Media is anything used to send messsage(s) from the sender(s) to the receiver(s), so it can arouse the learners' thought, feeling, and interest to gear the students' learn (Sadiman et al, 2002). According to Ruis et al (2009) media is very useful in learning English. Based on the explaination, it can be concluded that learning media is a means or educational tool that can be used as an intermediary in the learning process to enhance the effectiveness of learning process. For a learning process, teaching media of a tool used in order to make communication and interaction between lecturer and students more effective.

According to Nasution (2003), module is a complete unit that stands alone and consists of a series of learning activities arranged to help students achieve a number of objectives formulated specifically and clearly. According to Meyer (in Lasmiyati, 2014) module is relatively short self-contained independent unit of instructional designed to achieve a limited set of specific and well-defined educational objectives. Based on the explanation above it can be concluded that the module is a tool or means of learning in which it can be in the form of materials, methods, and evaluations made systematically and structured as an effort to achieve the objectives of the expected competence. Module is designed specifically and clearly based on the speed of understanding of each student, thus encouraging students to learn according to their ability.

Component of module in Dasna et all. (2006) consists of three parts, namely: introduction, contents, and end. The introductory section consists of cover, introduction, table of contents, guide for readers. The content section consists of the division of subject matter, each of which consists of several components: subtitles, student worksheets, material descriptions, and questions. The final section contains glossary and bibliography. Module development has certain components that must be considered by a lecturer because a module has an important role for both teachers and students. With the module that fits the characteristics of students and learning objectives, the level of students' understanding of the lesson will increase. Module is one of the principles of applying individual learning. With the module, students are free to implement learning according to the speed and opportunity of each. More importantly, students are no longer passively listening to the lectures from the leacturer, but students are expected to actively respond the learning process by listening, reading, evaluating, witnessing demonstrations, and interacting with fellow students and lecturer.

According to Hutchinson and Walters (in Puspitasari, 2013), ESP is an approach in the language teaching where content and methods are based on the students' reason to learn. ESP is a specific learning.

English for Computer Science is a teaching approach in order to achieve the goals or competence of the students to master English in the field of 
computers. Computer Science is one of the majors at Muhammadiyah University of Metro Lampung which aims at preparing the students to face the global world. The students of this department are expected to know things related to the computer science field especially know how to solve computer problems, how to design computer network and to understand computer components. Therefore, on graduating from the department, the students can directly work. One of the ways to prepare the students to be as expected is by giving them English. When the students are qualified, they will be able to apply for a job successfully.

\section{RESEARCH METHOD}

This type of research includes research and development (R\&D) method, research methods used to produce the interest of learning students in learning Computer Science Students of vocabulary mastery. This research is intended to produce an English learning media product, in the form of Module learning Computer Science, The model used in this development research is the ADDIE model which is a learning design a model consist of five stages including analysis, design, development, implementation and evaluation. The Procedure of research used in the researcher and this development use the ADDIE model developed by Dick and Carry (In Mulyatiningsih, 2011), as follows:

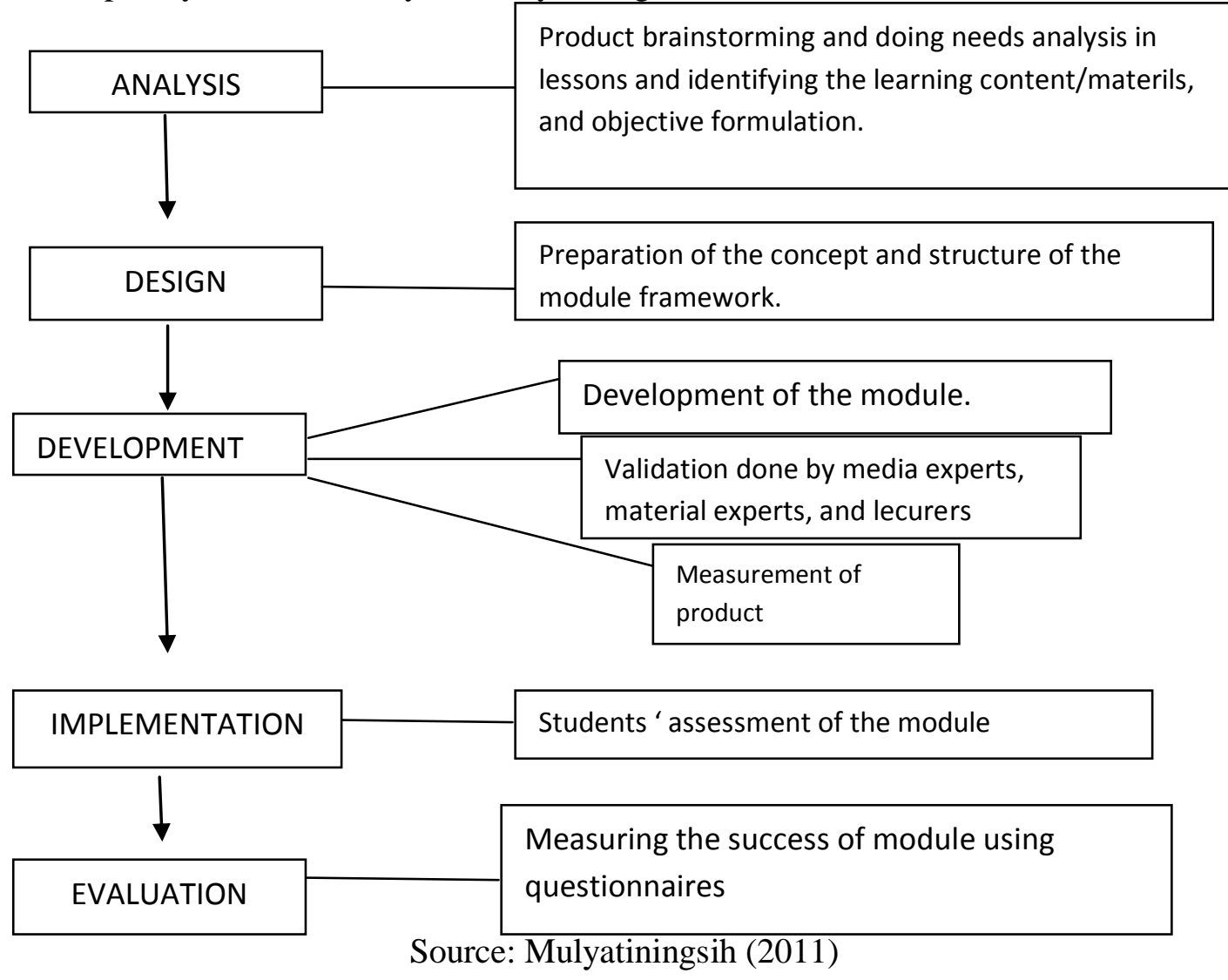


The subject of this research are, the lecturer of Computer Science Department of Muhammadiyah University of Metro (to provide input on the materials used), material experts, media experts, the lecturers majoring in English education and the second semester students of Computer Science Department of Muhammadiyah University of Metro amounted to 29 students.To get the data, these followings thing were used:

\section{Questionnaire}

The questionnaire is a technique of data collection conducted by giving a set of questions or written statement to the respondent to be answered (Sugiyono, 2015). The Questionnaire is a written question or statements that is used to obtain information or matters related to student responses to learning an English for Vocabulary mastery by using Module media as a source of independent learning. Questionnaires used to collect data in this study includes:

a. Questionnaire for material expert and a lecturer Computer Science.

b. Questionnaires for media experts

c. Questionnaires for lecturers of Computer Science Department

d. Questionnaire for students.

\section{Interview}

Interview is conducted to obtain information about the media used previously. And to know the extent of the students interest in learning English. Interview is also used as guidelines for asking the material to be summarized in the Module media.

The alternative answers using the Likert Scale provided for the media feasibility questionnaire with 5 alternative answers, which are very good, good, fair, less, poor.

The item scoring criteria on the media feasibility questionnaire.

\begin{tabular}{cc}
\hline Criteria & Scoring \\
\hline Very Good & 5 \\
Good & 4 \\
Fair & 3 \\
Less & 2 \\
Poor & 1 \\
\hline Source; Sugiyono (2015)
\end{tabular}

The steps of analyzing Module ESP the media quality data are:

a. Change the qualitative value to quantitative by using a Likert Scale with the following conditions:

$\begin{array}{ll}\text { very good } & : 5 \\ \text { good } & : 4 \\ \text { fair } & : 3 \\ \text { less } & : 2 \\ \text { poor } & : 1\end{array}$


b. Then the data collected is analyzed by calculating the average score obtained by the formula:

$$
\xi \sim=\frac{\sum x}{n}
$$

Legend:

$\xi \sim \quad=$ Average Score

$\Sigma \quad=$ Total Score

$\mathrm{n} \quad=$ Number of Item

c. The average results of the assessment obtained in the form of quantitative data are converted back into qualitative data on the module eligibility category so that it can be concluded about the Module's eligibility based on the ideal conversion guidelines described in the following table.

Legend:

Guide to the convention on scores

\begin{tabular}{cll}
\hline No & Formula & Categories \\
\hline 1 & $\mathrm{X}>x \sim_{i}+1,8 S B_{i}$ & Very Good \\
2 & $x \sim_{i}+0,6 S B_{i}<\mathrm{x} \leq$ & Good \\
& $x \sim_{i}+1,8 S B$ & \\
3 & $x \sim_{i}+0,6 S B_{i}<\mathrm{x} \leq \quad$ Fair \\
& $x \sim_{i}+0,6 S B_{i}$ & \\
4 & $x \sim_{i}-1,8 \quad S B_{i}<\quad \mathrm{x} \quad$ Less \\
& $\leq x \sim_{i}-0,6 S B_{i}$ & \\
5 & $\mathrm{X} \leq x \sim_{i}-1,8 S B_{i}$ & Poor \\
\hline
\end{tabular}

Source : Sukardjo (2012)

$x \sim_{i}=($ Ideal rate $)$

$\frac{1}{2}($ ideal max score + ideal min score $)$

$\left\langle B_{i}=\right.$ (Ideal standard deviation)

$1 / 6$ (ideal max score - ideal min score)

$X=$ Actual Score

Based on the above formula, we can get guidance of converting quantitative value 1 to 5 into qualitative category to conclude how media feasibility developed. If the $p \sim$ and $S B_{i}$ values are substituted on the formulas in the table, then the conversion guidelines will be obtained: 
Criteria of rating category

\begin{tabular}{|c|c|c|}
\hline No & $\begin{array}{l}\text { The range score of } \\
\text { quantitative }\end{array}$ & $\begin{array}{c}\text { The range } \\
\text { score of } \\
\text { quantitative }\end{array}$ \\
\hline 1 & $p \sim 80 \%$ & Very Good \\
\hline 2 & $66,67 \%<p \sim \leq 80 \%$ & Good \\
\hline 3 & $\begin{array}{l}53,33 \%<p \sim \leq \\
66,67 \%\end{array}$ & Fair \\
\hline 4 & $40 \%<p \sim \leq 53,33 \%$ & Less \\
\hline 5 & $p \sim \leq 40 \%$ & Poor \\
\hline \multicolumn{3}{|c|}{$\begin{array}{l}\text { Source: Research Data on Processed Development } \\
\text { entase) }\end{array}$} \\
\hline \multicolumn{3}{|c|}{ eal maximum score + ideal minimum score) } \\
\hline \multicolumn{3}{|c|}{$\begin{array}{l}1 / 6 \text { (ideal maximum score - ideal minimum score) } \\
1 / 6(5-1) \\
0.67\end{array}$} \\
\hline
\end{tabular}

\section{The Student response data}

The students' response towards the module of English for Computer Science were taken from 35 students who filled the questionnaire containing 20 questions. The answer from these students were categorized into: $1=$ disagree, $2=$ less agree, $3=$ hesitate, $4=$ agree, $5=$ strongly agree. Agree and strongly agree answers are considered positive. Meanwhile, disagree, less agree, and hesitate answers belong to negative response. The percentage of students' response is calculated using the formula below:

Legend:

$$
\% P=\frac{F}{N} \times 100 \%
$$

$\% P=$ percentage score

$F=$ frequency

$N=$ total number of respondents

The student's response is said to be positive if the average percentage of student responses is greater than or equal to $60 \%$.

The following table shows the frequency distribution of respondents response to the product: 


\begin{tabular}{cc}
\hline Category Response & Category Score \\
\hline Very Positive & $80<\mathrm{p} \leq 100$ \\
Positive & $60<\mathrm{p} \leq 80$ \\
Negative & $40<\mathrm{p} \leq 60$ \\
Very Negative & $20<\mathrm{p} \leq 40$ \\
Source: Research Data on Processed Development
\end{tabular}

\section{FINDING AND DISCUSSION}

To know the eligibility of the developed modules, it was done through some validation processes by some experts.

Product approriateness validation for a module was done by a material expert, media expert, and lecturers of Computer Science Department. After that it was done module revision process done with the students of Computer Science Department. The result of this process was the decision whether the module is worth to test in the field or not. After that, the module was implemented among the Computer Science students of the second semester. Field trials were conducted with 29 students. The researcher introduced the module, explained the contents of the module, then explained the benefits of modules for learning of Computer Science subject. After that, the researcher did practice teaching to the students. The students looked very enthusiastic when learning English using the module.

After learning using the module, the students assessed the module through a questionnaire. The researcher provided questionnaires containing 20 questions to 29 students. The questionnaire used Likert scale of 1-5. This functions to obtain the data of the students interest towards the module. Based on the questionnaire response it showed that the module, which was developed under aspects of motivation, interest, and media visualization, got students' positive response. The total score was 2034 and the percentage was 69,63\% which was the range of $60<\mathrm{P} \leq 80 \%$. For the conclusion, the module got "B" score and was in positive category.

To know the students' response towards the module, it was done through interview. The interview results showed that the students were interested and more motivated in following the lesson by using the English module. In addition, the students informed that the English module made the learning interesting. In sum, the results of the interviews showed that the students gave good response towards the use of module during the learning process.

\section{CONCLUSION}

Based on the results of the research, it can be concluded that the module of ESP for students of Computer Science Department of Muhammadiyah University of Metro is eligible and therefore can be used for English learning media. However, it's suggested that the next researches can be focused on developing English materials for Computer Science and Networking Program which specializing in other skills, such as writing, speaking, and reading. It is 
also suggested for other material developers to emphasize the needs of the learners since the essential point in developing materials for students of Computer Science is laid to the relevant content of their study.

\section{REFERENCES}

Dasna, Parlan \& Rita Susilawati.(2006). Pengembangan bahan ajar kimia SMPuntuk pengajaran materi bahan kimia rumah tangga. Jurnal Pendidikan danpembelajaran 13 (2): 197-208.

Endang Mulyatiningsih. (2011). Riset Terapan Bidang Pendidikan dan Teknik. Yogyakarta:UNY Press

Handayani.(2007).Look Ahead An English.Jakarta:Erlangga.

Hornby, AS.(2009) Oxford Advanced Learner's Dictionary, New York: Oxxford University Press.

Lasmiyati.(2014).Pengembangan Modul Pembelajaran untuk meingkatkan peemahaman konsep dan minat SMP.Universitas Muhammadiyah Surakarta

Nasution, S.(2003) Berbagai Pendekatan dalam proses Belajar dan Mengajar, Jakarta:Bumi Aksara.

Puspitasari, Indah. (2013). English For Computer Science : Sebuah Analisis Kebutuhan Bahasa Inggris Pada Mahasiswa Teknik Informatika.STMIK AMIKOM Purwokerto.

Ruis N.Muhyidin.Waluyo T.(2009).Instructional Media.Jakarta:Ministry of National Education.

Sadiman,Arief S. Et al.(2002) Media Pendidikan:Pengertian, Pengembangan dan Pemanfaatannya.Jakarta:PT.Raja Grafindo Persada.

Sugiyono. (2009). Metode Penelitian Pendidikan Pendekatan Kuantitatif, Kualitatif, dan $R \& D$. Bandung : Alfabeta.

Alfabet. (2015). Metode Penelitian Kuantitatif Kualitatif dan R\&D. Bandung:

Sukardjo. (2012). Evaluasi Pembelajaran Semester 2. Yogyakarta: Pps UNY Tanto, Fahri. (2014). Developing English Learning Material For Vocabulary Mastery Based On Word Gmes Technique At First Semester Of Eleventh Grade Of Senior High School. Universitas Muhammadiyah Metro. 